\title{
Semiautomatic Bioluminescence Determination of Glycerol Using a Computer Controlled Luminescence Analyser (Berthold LB 950 T)
}

\author{
By E. Wieland, Birgitta Fischer and H. Kather \\ Klinisches Institut für Herzinfarktforschung and der Medizinischen Universitätsklinik Heidelberg, Heidelberg
}

(Received May 28/September 20, 1984)

Summary: A semiautomatic determination of glycerol is described, in which luminescence produced by bacterial NADH-linked luciferase is measured by an automatic luminescence analyser (Berthold LB $950 \mathrm{~T}$ ).

The glycerol determination is based on the enzymatic conversion of glycerol to 3-phosphoglycerate, made irreversible by the presence of arsenate. NADH, formed in the glycercl-3-phosphate and glyceraldehyde-3phosphate dehydrogenase reactions, is subsequently determined by the bacterial luciferase system. Stable kinetics of light emission were obtained by reducing the catalytic concentration of NAD(P)H: FMN oxidoreductase from $85 \mathrm{U} / 1$ to $8.5 \mathrm{U} / 1$. This method was applied to serum samples and validated by comparison with an enzymatic fluorimetric method.

The new method is approximately 10 times more sensitive than the fluorimetric one. Moreover, it is simpler, more convenient, less time consuming and also less expensive than spectrophotometric, fluorimetric or radiochemical methods used for glycerol determination.

Halbautomatische bioluminometrische Glycerinbestimmung mit einem Computer-gesteuerten Lumineszenzmeßgerät (Berthold LB $950 \mathrm{~T}$ )

Zusammenfassung: Es wird eine semiautomatische Biolumineszenzmethode zur Bestimmung von Glycerin mit Hilfe bakterieller NADH-gekoppelter Luciferase und eines automatischen Lumineszenzmeßgerätes (Berthold LB 950 T) beschrieben.

Die Bestimmung basiert auf der Umwandlung von Glycerin zu 3-Phosphoglycerat, die in Anwesenheit von Arsenat irreversibel verläuft. In einem 2. Schritt wird das gebildete NADH bestimmt.

Durch Verminderung der katalytischen Kọnzentration von NAD(P)H: FMN-Oxidoreductase im Medium von $85 \mathrm{U} / 1$ auf 8,5 U/1 liẹ sich ẹin stabiles Lichtsignal erżielen. Die Methode wurde erfolgreich zur Analyse von Serumproben verwendet und durch Vergleich mit einer fluorimetrischen Methode überprüft.

Die vorgestellte Methode ist etwa 10mal empfindlicher als die Vergleichsmethode. Darüberhinaus ist sie einfach, bequem, schnell und billig.

\section{Introduction}

Although luminescence assays can be both sensitive and specific, their routine application has been hampered by the lack of suitable automatic lu- minometers. The latter have become available over the past two years and have subsequently led to a reduction in manpower and reagent costs in this laboratory. 
A bioluminescence method for the determination of glycerol has been developed in this laboratory $(1-3)$, which is at least 100 times more sensitive than the conventional spectrophotometric assays used in routine clinical chemistry.

The reaction sequence is shown in figure 1 . The phosphorylation and oxidation of glycerol to dihydroxyacetone phosphate are performed in the same way as in the spectrophotometric method. The next step normally involves the trapping of dihydroxyacetone phosphate with hydrazine (4). However, hydrazine reduces the light-output in the bioluminescence method, so the triosephosphate isomerase reaction sequence was used, and arsenate was included to prevent the reverse reaction of glyceraldehyde-3phosphate dehydrogenase (5). The NADH produced was used to generate light with an NAD(P)H-dependent luciferase.

The original method was completely manual and was therefore unsuitable for large numbers of samples. For the determination of glycerol levels in isolated fat cells using Krebs-Henseleit bicarbonate buffer, it was necessary to devise a medium devoid of enzymes or substrates likely to interfere with the luminescence determination.

The adaptation of the method to the measurement of serum glycerol with the LB $950 \mathrm{~T}$ automatic luminometer made it possible to increase the sample throughput. Our modified assay was compared with a fluorimetric method (6) using serum samples. The results showed that the automated luminescence assay provides a rapid and sensitive means of measuring serum glycerol levels, although impurities of the reagents involved in the glycerol reaction rendered it necessary to dilute the serum samples before measurement.

\section{i 1}

\section{Material and Methods}

\section{Chemicals}

All enzymes and coenzymes used for conversion of glycerol and for luminescence were obtained from Boehringer Mannheim, West-Germany. Tetradecanal and raffinose were obtained from EGA Chemie, Steinheim, Wèst-Germany and from Sigma, München, West-Germany, respectively.

\section{Pretreatment of serum and plasma}

Native serum or plasma $(0.05 \mathrm{ml})$ was treated with $0.05 \mathrm{ml}$ $1 \mathrm{~mol} / \mathrm{l} \mathrm{HCl}$ to inactivate any dehydrogenases that might interfere. One minute later the sample was neutralized by adding $0.05 \mathrm{ml} 1 \mathrm{~mol} / 1 \mathrm{NaOH}$ and 5-15 times diluted with deionized water.

\section{Conversion of glycerol}

Diluted (5-15 times) sample $(0.05 \mathrm{ml})$ was added to an equal volume of a medium composed of $28 \mathrm{mmol} / \mathrm{l}$ Triethanolamine$\mathrm{HCl}, 1.1 \mathrm{mmöl} / 1$ potassium dihydrogen phosphate $\left(\mathrm{KH}_{2} \mathrm{PO}_{4}\right)$, $20 \mathrm{mmol} / \mathrm{l}$ sodium arsenate $\left(\mathrm{Na}_{3} \mathrm{AsO}_{4}\right), 1.1 \mathrm{mmol} / \mathrm{l}$ dithiotreitol, $2.9 \mathrm{mmol} / \mathrm{l}$ magnesium chloride $\left(\mathrm{MgCl}_{2} \cdot 6 \mathrm{H}_{2} \mathrm{O}\right), 1.54$ $\mathrm{mmol} / \mathrm{l}$ ATP, $8.0 \mathrm{mmol} / \mathrm{l} \mathrm{NAD}^{+}, 7 \mathrm{kU} / \mathrm{l}$ glycerokinase, $19 \mathrm{kU} / 1$ glyceraldehyde-3-phosphate dehydrogenase, $2.3 \mathrm{kU} / 1$ glycerol-3-phosphate dehydrogenase and $33 \mathrm{kU} / \mathrm{l}$ triose phosphate isomerase. After incubation for 120 minutes at $25^{\circ} \mathrm{C}$ the samples were further diluted (6 times) and $0.01 \mathrm{ml}$ aliquots of the diluted media were assayed for NADH content.

(1) Glycerol + ATP $\rightleftharpoons$ Glycerokinase $\rightleftharpoons$ Glycerol-3-P + ADP

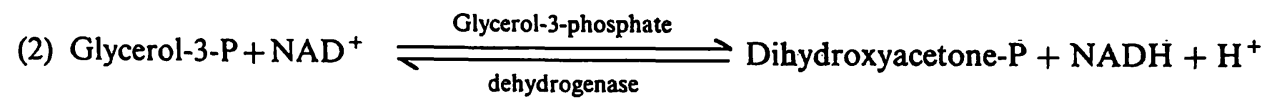

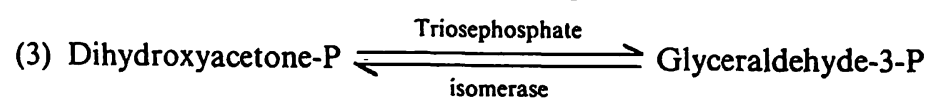

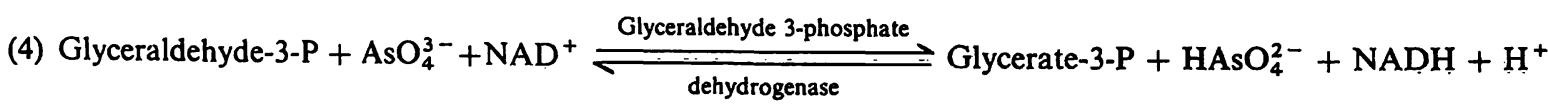

(5) $\mathrm{NADH}+\mathrm{H}^{+}+\mathrm{FMN} \underset{\text { oxidoreductase }}{\stackrel{\mathrm{NAD}(\mathrm{P}) \mathrm{H}: \mathrm{FMN}}{\rightleftharpoons}} \mathrm{FMNH}_{2}+\mathrm{NAD}^{+}$

(6) $\mathrm{FMNH}_{2}+\mathrm{R}-\mathrm{CHO}+\mathrm{O}_{2} \longrightarrow$ Luciferase $\longrightarrow \cdot \mathrm{R}-\mathrm{COOH}+\mathrm{FMN}+\mathrm{h} \cdot \mathrm{v}$

Fig. 1. Principle of enzymatic glycerol conversion (1 -4) and of light production by the NADH-linked luciferase system (5-6). Enzymes:

Glycerokinase, ATP: glycerol-3-phosphotransferase, EC 2.7.1.30

Glycerol 3-phosphate dehydrogenase, sn-glycerol-3-phosphate: NAD ${ }^{+}$oxidoreductase, EC 1.1.1.8

Triosephosphate isomerase, $D$-glyceraldehyde 3-phosphate ketol-isomerase, EC 5.3.1.1

Glyceraldehyde 3-phosphate dehydrogenase, $D$-glyceraldehyde 3-phosphate: NAD ${ }^{+}$oxidoreductase (phosphorylating) EC 1.2.1.12

NAD(P)H: FMN oxidoreductase, EC 1.6.8.1

Luciferase, alkanal, reduced FMN: oxygen oxidoreductase (1-hydroxylating, luminescing), EC 1.14.14.3. .; 


\section{Bioluminescent assay}

Luciferase (1.5 U/1) and NAD(P)H: FMN oxidoreductase (1.7 $\mathrm{kU} / \mathrm{l})$ were dissolved in a potassium phosphate buffer ( $0.2 \mathrm{~mol} / \mathrm{l}$ ) containing $0.4 \mathrm{mmol} / \mathrm{l}$ dithiotreitol and $67 \mathrm{mmol} / \mathrm{l}$ raffinose. Tetradecanal $(4.7 \mathrm{mmol} / \mathrm{l})$ was dissolved in a solution containing $50 \mathrm{~g} / 1$ of bovine serum albumin, $\mathrm{pH} 7.0$ at $50^{\circ} \mathrm{C}$.

Solutions of tetradecanal and luciferase were divided into small portions and stored at $-20^{\circ} \mathrm{C}$. Flavin mononucleotide $(0.11 \mathrm{mmol} / \mathrm{l})$ was dissolved in a potassium phosphate buffer $(2 \mathrm{mmol} / \mathrm{l}, \mathrm{pH} 7.0)$ and kept in a dark bottle on ice. The solution was prepared fresh every day. The assay cocktail $(100 \mathrm{ml})$ contained $0.5 \mathrm{mmol} / \mathrm{l}$ tetradecanal, $1.1 \mu \mathrm{mol} / 1$ flavin mononucleotide, $15 \mathrm{U} / \mathrm{l}$ luciferase and $8.5 \mathrm{U} / 1 \mathrm{NAD}(\mathrm{P}) \mathrm{H}$ : $F M N$ oxidoreductase. For the manual determination $5.25 \mathrm{mU} / 1$ luciferase and $85 \mathrm{U} / 1 \mathrm{NAD}(\mathrm{P}) \mathrm{H}$ : FMN oxidoreductase were used.

The assay cocktail was prepared daily and kept at $+2^{\circ} \mathrm{C}$ during measurements.

Light production was measured by a microcomputer-controlled automatic luminescence analyser (Berthold LB $950 \mathrm{~T}$ ). The measuring time was $15 \mathrm{~s}$. Integrated counts between 10 and 15 seconds were taken as the measure of the NADH concentration. The vials containing $0.01 \mathrm{ml}$ of sample were moved into their measuring position automatically. The reaction was started by the automatic injection of $0.25 \mathrm{ml}$ of the assay cocktail.

\section{Results}

Adaptation of reaction kinetics to automatic determination

The light kinetics produced in the bacterial bioluminescence reaction result in a relatively rapid increase in light emission followed by a somewhat slower decay of light intensity. In our previous method the height of the light peak, resulting from mixing the reagent and sample, was taken as a quantitative measure of NADH present in the sample (fig. 2a).

A stable level of light emission has considerably analytical advantages as compared to the conventional flash analysis. By means of stable kinetics it is possible to choose a convenient time interval to integrate and print out. It has previously been reported that the signal of bacterial luminescence will become reasonably stable when oxidoreductase is rate limiting (7). A constant level of light emission for at least 80 seconds can be obtained if oxidoreductase activities $(8.5 \mathrm{mU} / \mathrm{l})$ are chosen, being too low to convert more than a minute fraction of available NADH to $\mathrm{FMNH}_{2}$ during the measuring period (fig. 2b).

The instrument used is designed to do the complete assay (preincubation and measurement) fully automatically. Due to unknown impurities of enzymes and coenzymes used for the conversion of glycerol, however, relatively high blank readings are obtained, corresponding to $20-40 \%$ of the upper detection limit. The NADH formed during the preincubation therefore has to be diluted $6-10$ fold in order to reduce blank readings and to obtain a sufficient
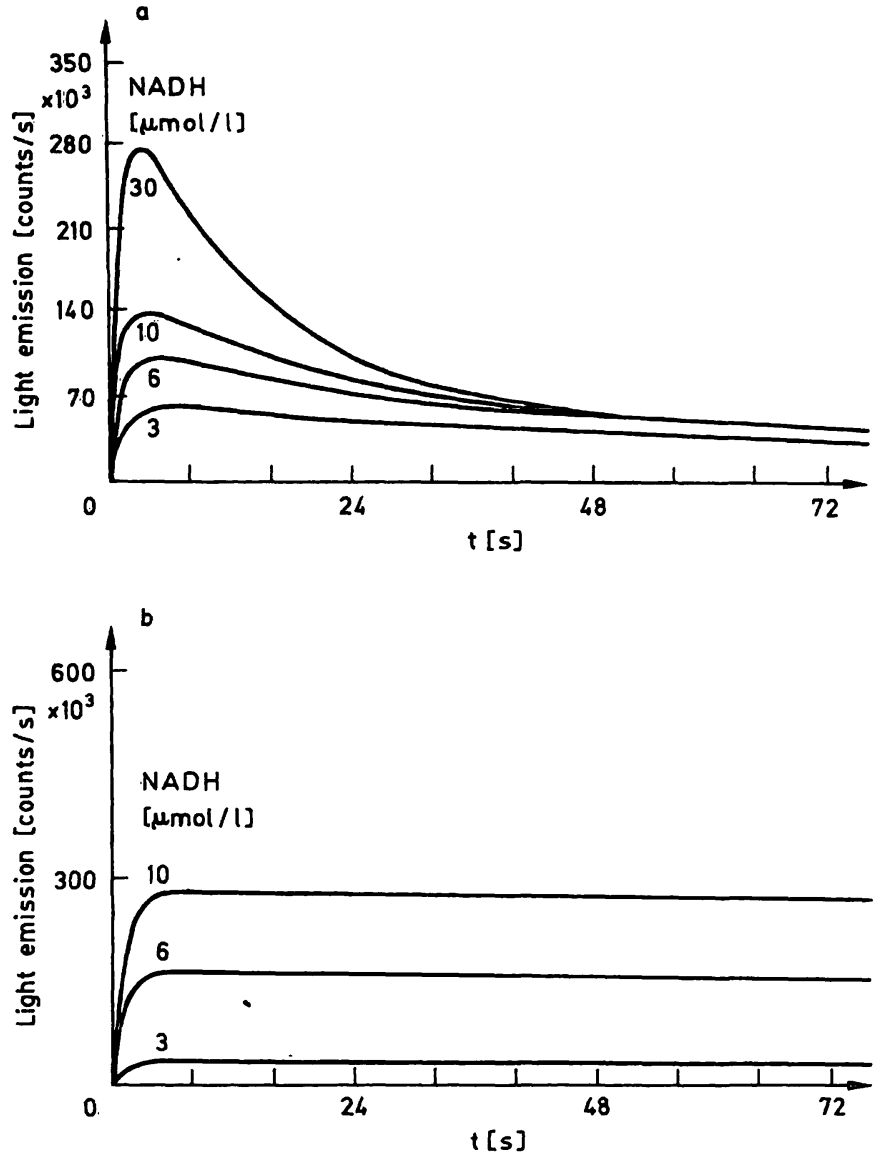

Fig. 2. Kinetics of light emission by the NADH-linked luciferase system.

a) peak measurement of NADH $(85 \mathrm{U} / 1 \mathrm{NAD}(\mathrm{P}) \mathrm{H}$ : FMN-oxidoreductase);

b) stable kinetics $(8.5 \mathrm{U} / 1 \mathrm{NAD}(\mathrm{P}) \mathrm{H}$ : FMN-oxidoreductase).

For experimental conditions see Materials and Methods. $\mathrm{NADH}$ was dissolved in deionized water.

dynamic range $(1 \mu \mathrm{mol} / 1-20 \mu \mathrm{mol} / 1$ of glycerol) (fig. 3). This dilution step presently precludes fully automatic measurements.

\section{Validation of method}

Within-day precision was estimated by determinating the glycerol content of one serum sample 20 times. Its mean value was $131.7 \mu \mathrm{mol} / 1$ with a standard deviation of 3.0 and a CV of $2.4 \%$. Analysis of one serum sample over a 5 day period showed a CV of $7 \%$ at a mean value of $118.5 \mu \mathrm{mol} / 1$ and a standard deviation of 9.0. The recovery of one glycerol concentration $(6.7 \mu \mathrm{mol} / \mathrm{l})$ added to 25 different appropriately diluted serum samples was in the range of $90-110 \%$. Accuracy was checked by comparison with the enzymatic fluorimetric method (6). For the linear regression, $r=0.99, y=0.66+1.03 x, n=$ 30 (fig. 4). Based on a signal to noise ratio of 1 the detection limit of the method is $1 \mu \mathrm{mol} / \mathrm{l}$ glycerol. This corresponds to less than $1 \mathrm{pmol} /$ assay. 


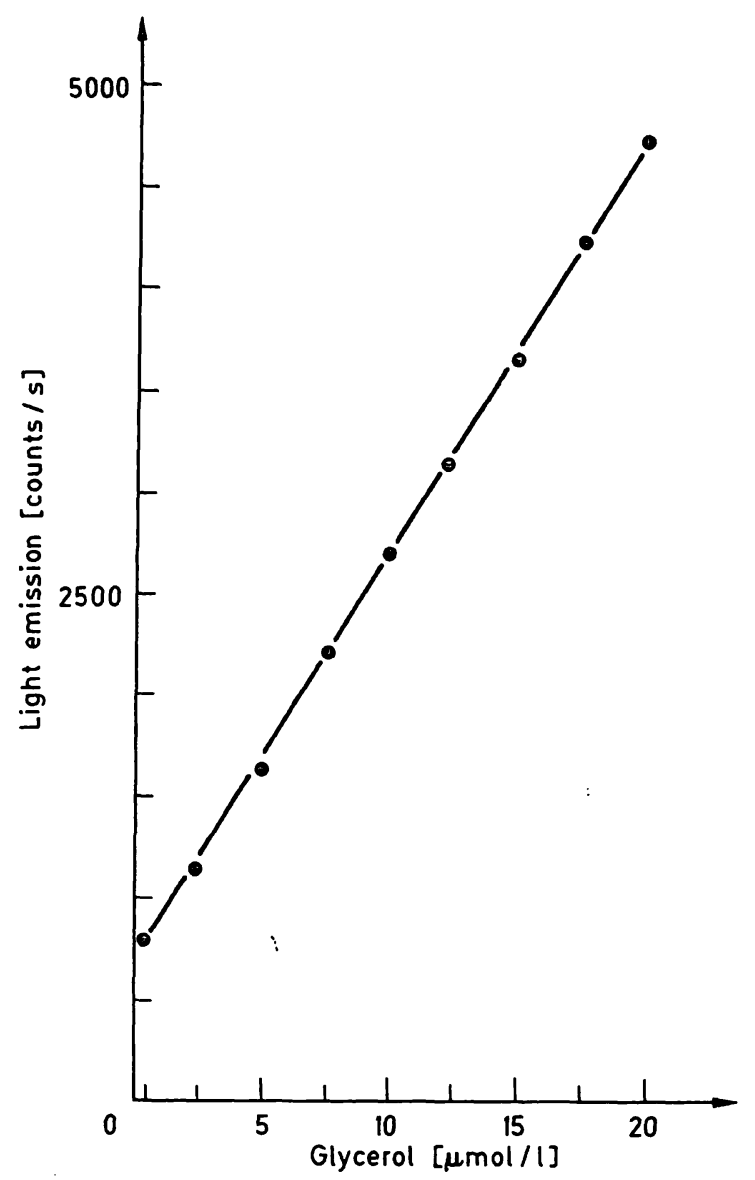

Fig. 3. Standard curve for glycerol $(1-20 \mu \mathrm{mol} / \mathrm{l})$. Values are means of duplicate determinations. Experimental conditions as described under Materials and Methods.

\section{Discussion}

Glycerol is released upon hydrolysis of triacylglycerol in vivo as well as in isolated cell systems in vitro. It is metabolized much more slowly than non esterified fatty acids in vivo and virtually not reused in isolated adipocytes. Glycerol, therefore, is generally used as an index of lipid mobilization in vivo and in vitro. The most commonly used methods for glycerol determination are based on conventional spectrophotometry, fluorimetry or conversion of radioactive tracers $(4,6,8)$. Among these approaches the photometric assay is of insufficient sensitivity for the determination of serum glycerol. Even its fluorimetric modification may not be sensitive enough to detect the extremely low concentrations of serum glycerol that occur during high carbohydrate feeding (9). The radiochemical method is hazardous and time consuming because it requires extensive purification of reaction products. If applied to in vitro studies with isolated fat cells, even the more sensitive of the above mentioned methods require large amounts of tissue or cells, because the least detectable concentration of glycerol is in the range of $10 \mu \mathrm{mol} / \mathrm{l}$.

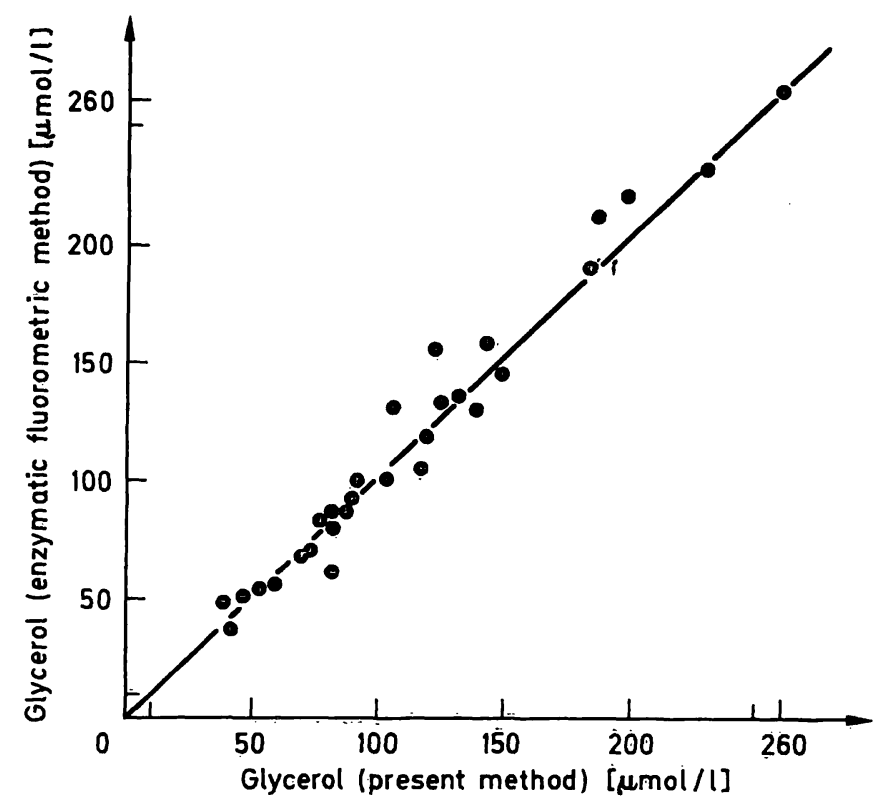

Fig. 4. Comparison of serum glycerol concentrations measured by the present method and by an enzymatic fluorimetric method $(r=0.99, y=1.03 x+0.66, n \equiv 30)$. Values are means of duplicate determinations. regression line, calculated.

The bioluminescence method for glycerol determination previously developed in our laboratory was designed for the manual determination of glycerol in incubation media of defined and relatively simple composition. This mànual methòd has been applied successfully for following lipolysis in microsamples of isolated adipocytes. At present approximately 250 cells in a total volume of $50 \mu \mathrm{l}$ are needed as a minimum $(1-3)$.

In contrast to the media usually employed for incubation of fat cells, serum may contain substances which degrade NADH. We found that acid treatment of sera inactivated these interfering compounds without causing appreciable hydrolysis of serum triglycerides. During preparation of this manuscript, Ramirez (10) in a short note, independently suggested almost the same procedure for estimating free fatty acids in rat or mouse plașma by a fluorimetric method. Approximately 200 determinations can now be carried out by one individual per day. Precision and accuracy are comparable with accepted methods. An excellent correlation exists with the fluorimetric method of Laurell \& Tibling (6). So far the method has only been applied to the determination of glycerol in serum samples. The method is in routine use in our laboratory. Even though a fairly complex coupled enzyme system is used for generation of NADH, more than 20.000 samples have now been successfully analysed. Currently efforts are being made to reduce the blank 
values in order to avoid the dilution of samples prior to NADH-determination. If blank values are sufficiently reduced, the above method could be applied to a fully automatic mode. Nevertheless, even

\section{References}

1. Kather, H., Schröder, F. \& Simon, B. (1980) Clin. Chim. Acta 120, 195-200.

2. Kather, H., Schröder, F. \& Simon, B. (1982) In: Luminescence Assay: Perspectives in Endocrinology and Clinical Chemistry, (Serio, M. \& Pazzagali, M. eds.) Raven Press, New York, pp. $53-56$.

3. Kather, H. \& Wieland, E. (1984) In: Methods of Enzymatic Analysis (Bergmeyer, H.U. ed.) Verlag Chemie, Weinheim und Academic Press, New York in press.

4. Wieland, O. (1974) In: Methods of Enzymatic Analysis, 2nd edition (Bergmeyer, H.U. ed.) Verlag Chemie, Weinheim und Academic Press, New York pp. 1404-1409.

5. Genovese, J., Schmidt, K. \& Katz, J. (1970) Anal. Biochem. $34,161-169$. in the present semiautomatic stage this method is simpler, quicker, more convenient and less expensive than spectrophotometric, fluorimetric or radiochemical methods.

6. Laurell, S. \& Tibbling, G. (1966) Clin. Chim. Acta 13, $317-322$.

7. Lavi, J. Raunio, R., Malkov, Y. \& Lövgren, T. (1983) Biochem. Biophys. Res. Commun. 111, 266-273.

8. Newsholme, E. A. (1974) In: Methods of Enzymatic Analysis, 2nd edition (Bergmeyer, H.U. ed.) Verlag Chemie Weinheim und Academic Press, New York, pp. 1409-1414.

9. Owen, O. E., Mozzoli, M.A., Boden, G., Patel, M.S., Reichard, G. A. Trapp, V., Shuman, C. R. \& Felig, P. (1980) Metabolism 29, $511-523$.

10. Ramirez, I. (1984) J. Lipid Res. 25, 92.

Dr. E. Wieland

Klinisches Institut für Herzinfarktforschung an der Medizinischen Universitätsklinik Heidelberg

Bergheimerstraße 58

D-6900 Heidelberg 
.

-

